\title{
SAINTIFIK-VISINGATAN \\ UNTUK MENINGKATKAN PENGETAHUAN MATERI GELOMBANG PADA SISWA KELAS \\ XI TKR 1 SEMESTER 1 SMK NEGERI 3 SEMARANG TAHUN PELAJARAN 2014/2015
}

\author{
Mahzum* \\ mahezfis@yahoo.com
}

\begin{abstract}
Abstrak
Rumusan masalah penelitian ini bagaimana proses mengaplikasikan pendekatan pembelajaran saintifik berbatuan media VISINGATAN untuk meningkatkan pengetahuan gelombang pada siswa kelas XI TKR 1 Semester 1 SMK Negeri 3 Semarang tahun pelajaran 2014/2015?. Desain penelitian menggunakan 2 siklus yang terdiri dari perencanaa, tindakan, observasi, dan refleksi.Terjadi peningkatan rata-rata nilai sikap 76,21 , nilai keterampilan 76,67 , nilai pengetahuan 76,52 pada siklus pertama menjadi rata-rata nilai sikap 80,31 , nilai keterampilan 81,52 , nilai pengetahuan 80,30 pada siklus kedua.
\end{abstract}

Kata Kunci: Pendekatan pembelajaran saintifik, VISINGATAN, pengetahuan materi gelombang

\section{PENDAHULUAN}

Gelombang merupakan materi berkarakter yang menuntut guru untuk kreatif dalam menyusun rencana pembelajaran. Karena konsep dasar gejala gelombang bersifat abstrak yang menyangkut rambatan energi akibat usikan. Pembuktian bentuk gelombang longitudinal yang memiliki rapatan dan regangan lebih rumit dibandingkan dengan membuktikan bentuk gelombang transversal yang memiliki bukit dan lembah.

Karakter gelombang menjadi unik karena perbedaan usikan/gangguan yang diberikan pada suatu benda akan menghasilkan bentuk gelombang yang berbeda pula. Padahal hakekatnya gelombang itu sama seperti yang disampaikan Endarko (2008: 283) bahwa gelombang merambatkan energi. Hal ini menggelitik pemikiran setiap orang terutama guru mata pelajaran fisika terhadap kehebatan fenomena alam ini. Terlebih jika membicarakan gelombang elektromagnetik, maka akan menemukan kesulitankesulitan manakala konsep dasar gejala gelombang tidak dikuasai dengan baik. karena materi ini hanya dapat diajarkan dengan analog dari konsep dasar gejala gelombang mengingat keterbatasan alat peraga untuk membuktikan gejala gelombang elektromagnetik. Karakter lain dari gelombang sebagai sumber kajian yang dapat membentuk attitude (sikap), membangun skill (keterampilan), dan knowledge (pengetahuan).

Pada awalnya guru mengajar dengan pendekatan pembelajaran Direct Instrustion (DI) berbasis ceramah, demonstrasi, dan resitasi pada materi gelombang. Sikap siswa kelas XI TKR 1 SMK Negeri 3 
Semarang karakter kesungguhan, rasa ingin tahu, kejujuran, tanggung jawab, dan toleransi yang dijadikan pengukuran guru dalam pembelajaran tersebut minimal harus sama dengan KKM yang dipatok 75 dan minimal berada pada kategori baik. Namun kenyataanya rata-rata nilai sikap hanya 74,75, dibawah KKM dan berada pada kategori cukup baik. Penguasaan keterampilan rata-rata nilai 75,25 sedikit berada di atas KKM dengan kategori kompeten. Namun demikian belum benar-benar mencerminkan kompetensi siswa. Karena pengambilan nilai keterampilan terbatas menghitung jumlah gelombang dan waktu yang dibutuhkan sementara praktikum media slinki dan garpu tala dilakukan oleh guru melalui demonstrasi. Sedangkan rata-rata pengetahuan siswa pada materi gelombang menunjukkan nilai 74,24 di bawah KKM dalam kategori tidak tuntas.

Fakta di atas menunjukan 2 masalah utama yaitu: 1) sikap siswa kelas XI TKR 1 Semester 1 SMK Negeri 3 Semarang Tahun Pelajaran 2014/2015 yang kurang baik pada materi gelombang. sikap ini dipicu oleh proses pembelajaran yang monoton, bersifat searah, dan terpusat pada guru. 2) pengetahuan siswa yang rendah terhadap materi gelombang akibat siswa kurang terkesan dengan materi tersebut. Dengan demikian diperlukan tindakan perbaikan terstruktur dan sistematis melalui aplikasi pendekatan saintifik berbantuan media VISINGATAN.

Rumusan Masalah yang diajukan adalah: 1) Bagaimana aplikasi pendekatan pembelajaran saintifik berbantuan media VISINGATAN pada materi gelombang? 2) Bagaimana perubahan sikap siswa kelas XI TKR 1 Semester 1 SMK Negeri 3 Semarang Tahun Pelajaran 2014/2015 setelah mengaplikasikan pendekatan pembelajaran saintifik berbantuan media VISINGATAN pada materi gelombang?. 3) Bagaimana peningkatan keterampilan siswa setelah mengaplikasikan pendekatan pembelajaran saintifik berbantuan media VISINGATAN pada materi gelombang?.4) Bagaimana peningkatan pengetahuan siswa setelah mengaplikasikan pendekatan pembelajaran saintifik berbantuan media VISINGATAN pada materi gelombang?.

Tujuan penelitian ini untuk:1) mendiskripsikan proses apilkasi pendekatan pembelajaran saintifik berbantuan media VISINGATAN pada materi gelombang bagi siswa SMK Negeri 3 semarang. 2) mendiskripsikan peningkatan sikap siswa SMK Negeri 3 Semarang setelah diaplikasikan pendekatan pembelajaran saintifik berbantuan media VISINGATAN pada materi gelombang. 3) mendiskripsikan peningkatan keterampilan siswa SMK Negeri 3 Semarang setelah diaplikasikan pendekatan pembelajaran saintifik berbantuan media VISINGATAN pada materi gelombang. 4) mendiskripsikan peningkatan pengetahuan siswa SMK Negeri 3 Semarang setelah diaplikasikan pendekatan pembelajaran saintifik berbantuan media VISINGATAN pada materi gelombang. 
Manfaat praktis dari penelitian ini bagi penulis untuk mengetahui peningkatan sikap,ketermpilan dan pengetahuan siswa SMK Negeri 3 Semarang terhadap materi gelombang. Bagi Kepala Sekolah sebagai bahan pertimbangan dalam hal peningkatan mutu pembelajaran. Dan bagi SMK Negeri 3 Semarang sebagai bahan bacaan guru/siswa. Sedangkan manfaat Teoritis sebagai bahan untuk mengembangkan ilmu pengetahuan tentang pendidikan khususnya peranan guru dalam meningkatkan sikap, ketermpilan dan pengetahuan siswa SMK Negeri 3 Semarang.

\section{METODE PENELITIAN}

Subyek penelitian ini adalah siswa kelas XI Semester 1 SMK Negeri 3 Semarang tahun pembelajaran 2014/2015 dengan jumlah siswa 33 seluruhnya laki-laki. Alasan pemilihan kelas ini karena sikap dan pengetahuan siswa terhadap materi gelombang kurang baik. Maka penilitian ini difokuskan pada peningkatan sikap dan pengetahuan siswa kelas XI semester 1 SMK Negeri 3 Semarang terhadap materi gelombang. Penelitian dilaksanakan selama 3 bulan sejak bulan Juli sampai dengan bulan September 2014. Bulan Juli digunakan untuk menyusun bab 1 sampai 3, bulan Agustus untuk mengambil data penelitian dalam tatap muka di kelas dan bulan September digunakan untuk menyusun laporan.

Desain penelitian menggunakan 2 siklus masing-masing siklus mengikuti prosedur PTK dengan mengikuti skema alur model Kurt Lewis dalam Rahman (2008:2) yang meliputi perencanaan, tindakan, observasi, dan refleksi. Sumber data penelitian ini diambil dari hasil observasi sikap dan keterampilan siswa selama proses pembelajaran, dan hasil uji kompetensi melalui tes. Teknik pengumpulan data menggunakan teknik dokumentasi dengan cara menganalisis daftar nilai siswa, teknik observasi sikap dan keterampilan untuk mengumpulkan data ketika tindakan penelitian dilakukan pada tiap siklus dan teknik tes untuk mengetahui pengetahuan siswa dengan bentuk soal pilihan ganda.

Indikator keberhasilan dari aplikasi penerapan pembelajaran saintifik berbantuan media VISINGATAN adalah: 1) memiliki sikap cukup baik (CB) jika $\mathrm{CB}<75$, sikap baik (B) jika $75 \leq \mathrm{B}<85$, dan sikap sangat baik (SB) jika $\mathrm{SB} \geq 85$. 2) memiliki keterampilan cukup kompeten (CK) jika CK $<75$, kompeten (K) jika $75 \leq K<85$, sangat kompeten (SK) jika SK $\geq 85$. 3) memiliki pengetahuan yang tuntas (T) jika $\mathrm{T} \geq 75$ dan tidak tuntas (TT) jika TT $<75$. 


\section{HASIL PENELITIAN DAN PEMBAHASANYA}

\section{Proses Pada Siklus I}

Proses pada siklus I terdiri dari 2 kali pertemuan. Pertemuan pertama pendekatan pembelajaran saintifik diaplikasikan pada materi gelombang berbantuan vidio, slinki, dan animasi. Perencanaan dengan menyiapkan seluruh perangkat pembelajaran, laptop, LCD, slinki dan meminta bantuan kolaborator sebagai observer. Pelaksanaan tindakan diawali dengan memotivasi siswa untuk berpikir kritis tentang dahsyatnya tsunami di Jepang. Selanjutnya siswa dibagi 7 kelompok diskusi yang terdiri dari 4-5 orang. Guru memutar video gelombang air laut dan tugas siswa mengamati serta menyusun pertanyaanpertanyaan yang berkaitan dengan fenomena air untuk dirumuskan menjadi masalah.

Selanjutnya tiap kelompok mengumpulkan informasi melalui diskusi studi literatur bahan ajar atau buku yang relevan untuk menemukan hipotesis dan melakukan percobaan dengan slinki yang didukung dengan penayangan animasi. Siswa diarahkan untuk mengolah atau menalar informasi dengan mencari keterkaitan antar informasi yang diperoleh dan meyimpulkan temuan-temuanya menjadi konsep atau teori. Satu kelompok diminta untuk mempresentasikan hasil diskusinya dan kelompok lain menanggapi dan memberi umpan balik. Selesai presentasi guru bersama siswa menyimpulkan konsep gelombang secara keseluruhan.

Pengamatan sikap dilakukan oleh kolaborator pada saat proses pembelajaran berlangsung dengan kompetensi kesungguhan, memiliki rasa ingin tahu, kerja keras, dan sikap toleran. Pengamatan keterampilan dilakukan oleh peneliti ketika peragaan slinki berlangsung.

Pada pertemuan kedua dilakukan tes pilihan ganda untuk mengukur pengetahuan siswa terhadap materi gelombang yang terdiri dari 20 butir soal pilihan ganda. Pada saat tes berlangsung kolaborator melakukan pengamatan kekejujuranan siswa dalam mengerjakan soal. Setelah tes selesai langsung dikoreksi dengan kolaborator dan hasil dari pengamatan dan tes dijadikan bahan refleksi.

\section{Hasil Penelitian Siklus I}

Data hasil penelitian tindakan kelas pada siklus pertama disajikan dalam tabel 1 sebagai berikut: Tabel 1: Hasil Analisis Nilai Sikap, Keterampilan, Pengetahuan Pada Siklus I

\begin{tabular}{|l|c|c|c|c|c|c|}
\hline Statistik & Sikap & Kategori & Keterampilan & Kategori & Pengetahuan & Kategori \\
\hline Jumlah & 33 & & 33 & & 33 & \\
\hline Mean & 76.21 & $\mathrm{~B}$ & 76.67 & $\mathrm{~K}$ & 76.52 & $\mathrm{~T}$ \\
\hline Mode & $75(66.67 \%)$ & $\mathrm{B}$ & $75(66.67 \%)$ & $\mathrm{K}$ & $75(48.48 \%)$ & $\mathrm{T}$ \\
\hline Minimum & $70(12.12 \%)$ & $\mathrm{CB}$ & $70(6.06 \%)$ & $\mathrm{CK}$ & $65(3.03 \%)$ & $\mathrm{TT}$ \\
\hline Nilai<KK & $12.12 \%$ & $\mathrm{CB}$ & $6.06 \%$ & $\mathrm{CK}$ & $18.18 \%$ & $\mathrm{TT}$ \\
\hline
\end{tabular}




\begin{tabular}{|l|l|l|l|l|l|l|}
\hline Maximum & $85(12.12 \%)$ & SB & $85(12.12 \%)$ & SK & $85(15.15 \%)$ & T \\
\hline
\end{tabular}

Dari hasil analisis pada tabel 1, nilai sikap menunjukkan mean 76,21. artinya rata-rata sikap pembelajaran peserta didik baik (B). Nilai sering muncul (mode) sebesar 75 berarti mayoritas peserta didik bersikap baik. Mean nilai keterampilan sebesar 76,67 artinya rata-rata peserta didik kompeten (K). Nilai mode 75,00 berarti mayoritas peserta didik kompeten. Mean nilai pengetahuan 76,52 artinya ratarata peserta didik nilai pengetahuanya tuntas $(\mathrm{T})$. Mode nilai pengetahuan sebesar 75 berarti mayoritas peserta didik tuntas.

Refleksi pada siklus pertama dirumuskan sebagai berikut: 1) masih terdapat 6\%-18\% peserta didik yang mendapat nilai sikap, nilai keterampilan, dan nilai pengetahuan di bawah KKM dengan kategori cukup baik, cukup kompeten, dan tidak tuntas. 2) nilai mean dan mode sikap, keterampilan, dan pengetahuan nyaris sama dengan KKM menunjukkan kondisi sikap, keterampilan, dan pengetahuan siswa pas-pasan.3) siswa yang mendapat nilai maksimum hanya 12\%-15\%. Walaupun nilai maksimum 85 berkategori sangat baik, sangat kompeten, dan tuntas, namun nyaris sama dengan kategori baik dan kompeten. Dari refleksi tersebut, maka diperlukan tindakan lebih lanjut agar pembelajaran dengan penerapan pendekatan saintifik berbantuan VISINGATAN menghasilkan pengetahuan yang lebih baik.

\section{Proses Pada Silkus II}

Pada pertemuan ketiga dalam siklus kedua pendekatan pembelajaran saintifik diaplikasikan pada materi gelombang bunyi berbantuan vidio, garpu tala dan animasi. Perencanaan Tindakan guru menyiapkan seluruh perangkat, media pembelajaran, dan meminta bantuan kolaborator sebagai observer. Pelaksanaan tindakan diawali memotivasi siswa dengan mengajak berfikir kritis tentang bunyi bom bali yang dahsyat terdengar dari radius yang jauh. Selanjutnya siswa dibagi 7 kelompok diskusi terdiri dari 4-5 orang dengan penyebaran anggota kelompok dari siklus pertama sehingga terjadi komposisi merata anggota yang tuntas dan yang tidak tuntas. Guru memutar video penerbangan jet supersonic dan tugas siswa mengamati dan menyusun pertanyaan-pertanyaan yang berkaitan dengan fenomena penerbangan jet tersebut untuk dirumuskan menjadi masalah. Tiap kelompok mengumpulkan informasi melalui diskusi studi literatur bahan ajar atau buku yang relevan dan menelaahnya untuk dirumuskan menjadi hipotesis. Tiap kelompok memperagakan garpu tala dan setelah peragaan diputar tayangan animasi.

Siswa diarahkan untuk mengolah atau menalar informasi dengan mencari keterkaitan antar informasi yang diperoleh sebagai bahan solusi permasalahan yang dihadapi dan meyimpulkan temuantemuanya menjadi konsep atau teori. Satu kelompok diminta untuk mempresentasikan hasil diskusinya 
dan kelompok lain menanggapi dan memberi umpan balik. Selesai presentasi guru bersama siswa menyimpulkan konsep bunyi secara keseluruhan.

Pengamatan sikap dilakukan oleh kolaborator pada saat pembelajaran berlangsung dengan kompetensi kesungguhan, memiliki rasa ingin tahu, sikap kejujuran, kerja keras, dan sikap toleran. Sedangkan Pengamatan keterampilan dilakukan oleh peneliti ketika tiap siswa memperagakan garpu tala

Pada pertemuan keempat dilakukan tes pilihan ganda untuk mengukur pengetahuan siswa terhadap materi gelombang bunyi yang terdiri dari 20 butir soal pilihan ganda. Pada saat tes berlangsung kolaborator melakukan pengamatan kekejujuranan siswa dalam mengerjakan soal. Setelah tes selesai langsung dikoreksi dengan kolaborator dan hasil dari pengamatan dan tes dijadikan bahan refleksi.

\section{Hasil Penelitian Siklus II}

Data hasil penelitian tindakan kelas pada siklus pertama disajikan dalam tabel 2 sebagai berikut: Tabel 2: Hasil Analisis Data Nilai Sikap, Keterampilan, Pengetahuan Siklus ke II

\begin{tabular}{|l|c|c|c|c|c|c|}
\hline \multicolumn{1}{|c|}{ Statistik } & Sikap & Kategori & Keterampilan & Kategori & Pengetahuan & Kategori \\
\hline Jumlah & 33 & & 33 & & 33 & \\
\hline Mean & 80.31 & $\mathrm{~B}$ & 81.52 & $\mathrm{~K}$ & 80.30 & $\mathrm{~T}$ \\
\hline Mode & $80(42.42 \%)$ & $\mathrm{B}$ & $80(51.51 \%)$ & $\mathrm{K}$ & $80(36.36 \%)$ & $\mathrm{T}$ \\
\hline Minimum & $75(36.36 \%)$ & $\mathrm{CB}$ & $75(27.27 \%)$ & $\mathrm{CK}$ & $70(3.03 \%)$ & $\mathrm{TT}$ \\
\hline Nilai<KKMM & $00.00 \%$ & $\mathrm{CB}$ & $00.00 \%$ & $\mathrm{CK}$ & $3.03 \%$ & $\mathrm{TT}$ \\
\hline Maximum & $95(3.03 \%)$ & $\mathrm{SB}$ & $95(9.09 \%)$ & SK & $90(9.09 \%)$ & $\mathrm{T}$ \\
\hline
\end{tabular}

Dari hasil analisis pada tabel 2, mean nilai sikap 80,31, artinya rata-rata sikap pembelajaran peserta didik baik (B). Nilai mode 80,00 berarti mayoritas peserta didik bersikap baik. Mean nilai keterampilan 81,52 artinya rata-rata peserta didik kompeten (K). Nilai mode 80,00 berarti mayoritas peserta didik kompeten. Mean nilai pengetahuan 80,30 artinya rata-rata hasil belajar pengetahuan peserta didik tuntas (T). Nilai mode 80 berarti mayoritas hasil belajar pengetahuan peserta didik tuntas.

Refleksi pada siklus kedua dirumuskan sebagai berikut: 1) tidak ada peserta didik yang mendapat nilai di bawah KKM. 2) mean dan mode sikap, keterampilan, dan pengetahuan jauh melampaui KKM. 3) nilai maksimum sikap, keterampilan, dan pengetahuan berada pada kategori sangat baik, sangat kompeten, dan tuntas dengan nilai tinggi, walaupun jumlah peserta didik pada kategori ini hanya 3,03\%-9,09\%. Memperhatikan refleksi pada siklus kedua tersebut, maka cukup memerlukan tindakan sampai pada siklus kedua dalam mengaplikasikan pendekatan saintifik berbantuan VISINGATAN pada pokok bahasan gelombang. 


\section{PEMBAHASAN}

Berdasarkan rekapitulasi analisis data siklus I dan siklus II pada tabel 3 tampak jelas dan nyata perubahan sikap, peningkatan keterampilan dan pengetahuan siswa kelas XI TKR 1 semester 1 SMK Negeri 3 Semarang tahun pelajaran 2014/2015.

Tabel 3: Rekapitulasi data hasil analisis siklus I dan II

\begin{tabular}{|l|c|c|c|c|c|c|c|c|}
\hline & \multicolumn{3}{|c|}{ rata-rata } & \multicolumn{5}{c|}{ rata-rata Kompetensi sikap } \\
\cline { 2 - 9 } & Sikap & $\begin{array}{c}\text { Kete } \\
\text { Rampilan }\end{array}$ & $\begin{array}{c}\text { Penge } \\
\text { tahuan }\end{array}$ & $\begin{array}{c}\text { Ke } \\
\text { sung } \\
\text { guhan }\end{array}$ & $\begin{array}{c}\text { Rasa } \\
\text { Ingin } \\
\text { Tahu }\end{array}$ & Jujur & $\begin{array}{c}\text { Kerja } \\
\text { Keras }\end{array}$ & $\begin{array}{r}\text { Tole } \\
\text { ransi }\end{array}$ \\
\hline Siklus 1 & 76.21 & 76.67 & 75.52 & 3.00 & 3.12 & 3.06 & 3.06 & 3.00 \\
\hline Siklus 2 & 80.31 & 81.52 & 80.30 & 3.58 & 3.12 & 3.18 & 3.15 & 3.03 \\
\hline
\end{tabular}

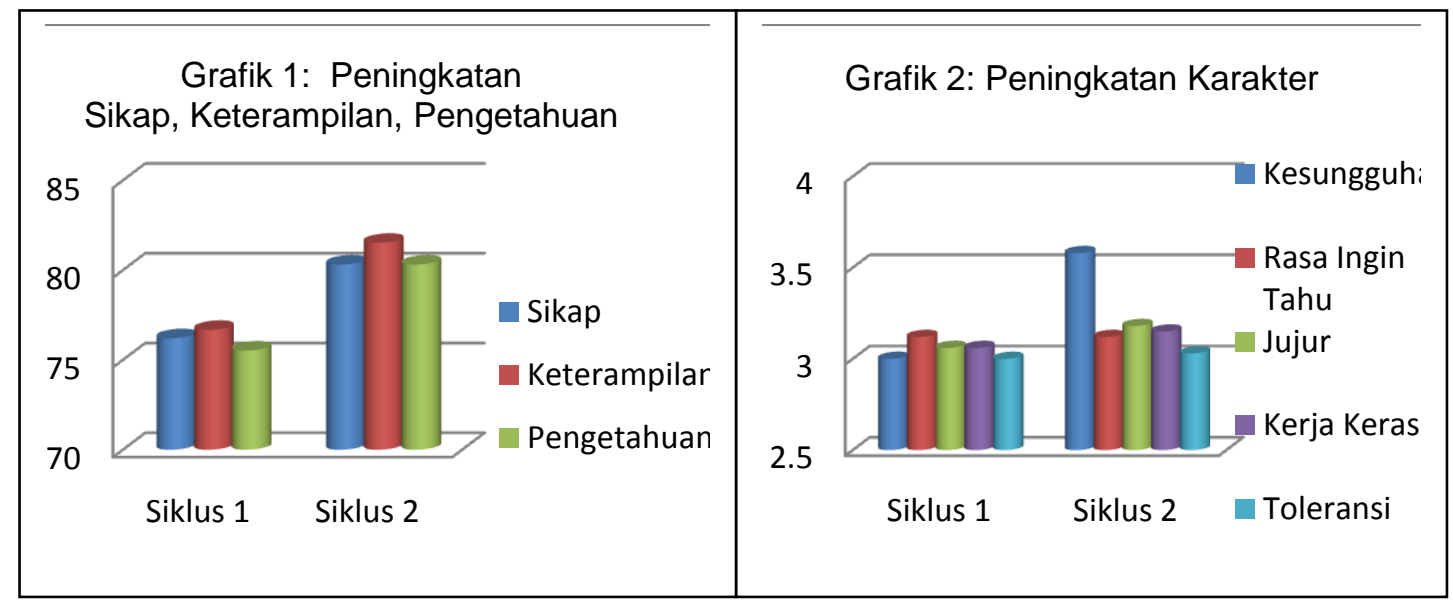

Dalam rekapan di atas rata-rata nilai sikap mengalami perubahan dari 76,21 menjadi 80,31. Ratarata nilai keterampilan meningkat dari 76,67 menjadi 81,52. Sedangkan rata-rata nilai pengetahuan meningkat dari 75,52 menjadi 80,30.

Dari grafik 1 peningkatan pengetahuan materi gelombang dari siklus I menjadi siklus II cukup signifikan walaupun masih terdapat $3.03 \%$ atau 1 siswa yang ketinggalan. Peningkatan ini tidak lepas dari faktor pendukung utamanya yaitu peningkatan sikap dan keterampilan siswa kelas XI semester 1 SMK Negeri 3 Semarang terhadap materi gelombang. Pondasi utama peningkatan pengetahuan siswa terhadap materi gelombang tercermin pada peningkatan sikap karena terjadi perubahan sikap siswa. Sikap siswa tergambar dengan jelas pada grafik 2 yaitu: kesungguhan dalam pengamatan, rasa ingin tahu ketika menanya, jujur dalam mengumpulkan informasi dari berbagai sumber, bekerja keras ketika berdiskusi untuk menelaah informasi, dan toleran ketika presentasi. Kelima sikap belajar tersebut mendorong setiap kelompok untuk mendapatkan hasil diskusi yang terbaik dan tampak dalam presentasi bahwa masing- 
masing kelompok berbeda pandangan dalam men sikapi fenomena peragaan tayangan video gelombang dan video penerbangan jet supersonic serta peragaan media slinki dan tayangan animasinya.

Diagram batang sikap kesungguhan siklus II berada pada posisi tertinggi. Dengan demikian sikap kesungguhan menjadi pondasi awal untuk memulai proses pembelajaran yang mempengaruhi peningkatan empat sikap lainya atau minimal mempertahankan sikap pada siklus pertama. Dengan lima sikap belajar tersebut, siswa mulai terbiasa berpikir mandiri secara kelompok maupun individu tanpa harus banyak dibimbing oleh guru. Pada siklus kedua ini guru hanya sebagai fasilitator dan siswa aktif dalam proses pembelajaran. Efeknya pengetahuan siswa pada siklus kedua meningkat tajam.

\section{KESIMPULAN}

Kesimpulan yang dapat disampaiakan dalam penelitian ini adalah: 1) Pada siklus I proses aplikasi pendekatan pembelajaran saintifik diberlakukan pada materi gelombang dengan bantuan media slinki yang diperagakan oleh tiap siswa dalam setiap kelompok. Sedangkan pada siklus II proses aplikasi pendekatan pembelajaran saintifik diberlakukan pada materi gelombang dengan bantuan media slinki yang diperagakan oleh setiap siswa dalam setiap kelompok. Namun anggota kelompok pada siklus II mengalami penyebaran dari kelompok pada siklus I berdasarkan ketuntasan belajarnya. Pada siklus II disamping berbantuan media slinki juga diputarkan animasi yang diamati oleh seluruh siswa setelah melakukan peragaan media slinki. 2) sikap siswa kelas XI TKR 1 Semester 1 SMK Negeri 3 Semarang Tahun Pelajaran 2014/2015 setelah mengaplikasikan pendekatan pembelajaran saintifik berbantuan media VISINGATAN pada materi gelombang berubah baik. 3) Keterampilan siswa siswa Kelas XI semester 1 SMK Negeri 3 Semarang tahun pelajaran 2014/2015 setelah mengaplikasikan pendekatan pembelajaran saintifik berbantuan media VISINGATAN pada materi gelombang mengalami peningkatan?. 4) Pengetahuan siswa Kelas XI semester 1 SMK Negeri 3 Semarang tahun pelajaran 2014/2015 setelah mengaplikasikan pendekatan pembelajaran saintifik berbantuan media VISINGATAN pada materi gelombang mengalami peningkatan. 


\section{DAFTAR PUSTAKA}

Azmi,Ulil.(2013).” Upaya Meningkatkan Hasil Belajar IPA Melalui Pendekatan Saintifik Metode Problem Based Pada Siswa Kelas V MI Al Islam Mangunsari 02 Kota Semarang Tahun Pelajaran 2013/2014”.Laporan Penelitian.

Endarko. 2008. Fisika Jilid 2 Untuk SMK Teknologi. Jakarta: Departemen Pendidikan Nasional.

Hikmah, Aslihatul. (2012) “Penerapan Pembelajaran Kooperatif Tipe Jigsaw Berbantuan LKS Untuk Meningkatkan Hasil Belajar Siswa Kelas X SMK Negeri 3 Semarang”.Laporan

Komalasari, Kokom, Pembelajaran Kontekstual, Bandung: PT. Refika Aditama, 2011.

Rachman, Maman .2008. Penelitian Tindakan Kelas.Semarang: Unnes.

Alamsyah, Nur.2013. Garpu Tala (Tune Fork). http://nuralamsyah5.blogspot.com/ 2013/10/garputala.html

Peraturan Menteri Pendidikan dan Kebudayaan Republik Indonesia Nomor 81A Tahun 2013 Tentang Implementasi Kurikulum.

Wardoyo, Mangun.2013. Pembelajaran Berbasis Riset. Purbalingga: Akademia.

Soetomo. 2011. Perancangan dan Pengembangan Sistem Pembelajaran. Semarang: YSBI Kanthil.

Subana, dkk. 2000,Statistik Pendidikan. Bandung: Pustaka Setia.

Rianto, Trinoto. 2013. Pengertian video. http://intstring.blogspot.com/2013/07/ pengertianvideo_4282.html

Yunus, Abidin. 2013.Desain Sistem Pembelajaran Dalam Koteks Kurikulum. Bandung: PT Rafika Aditama. 